Historic, Archive Document

Do not assume content reflects current scientific knowledge, policies, or practices. 
4. 


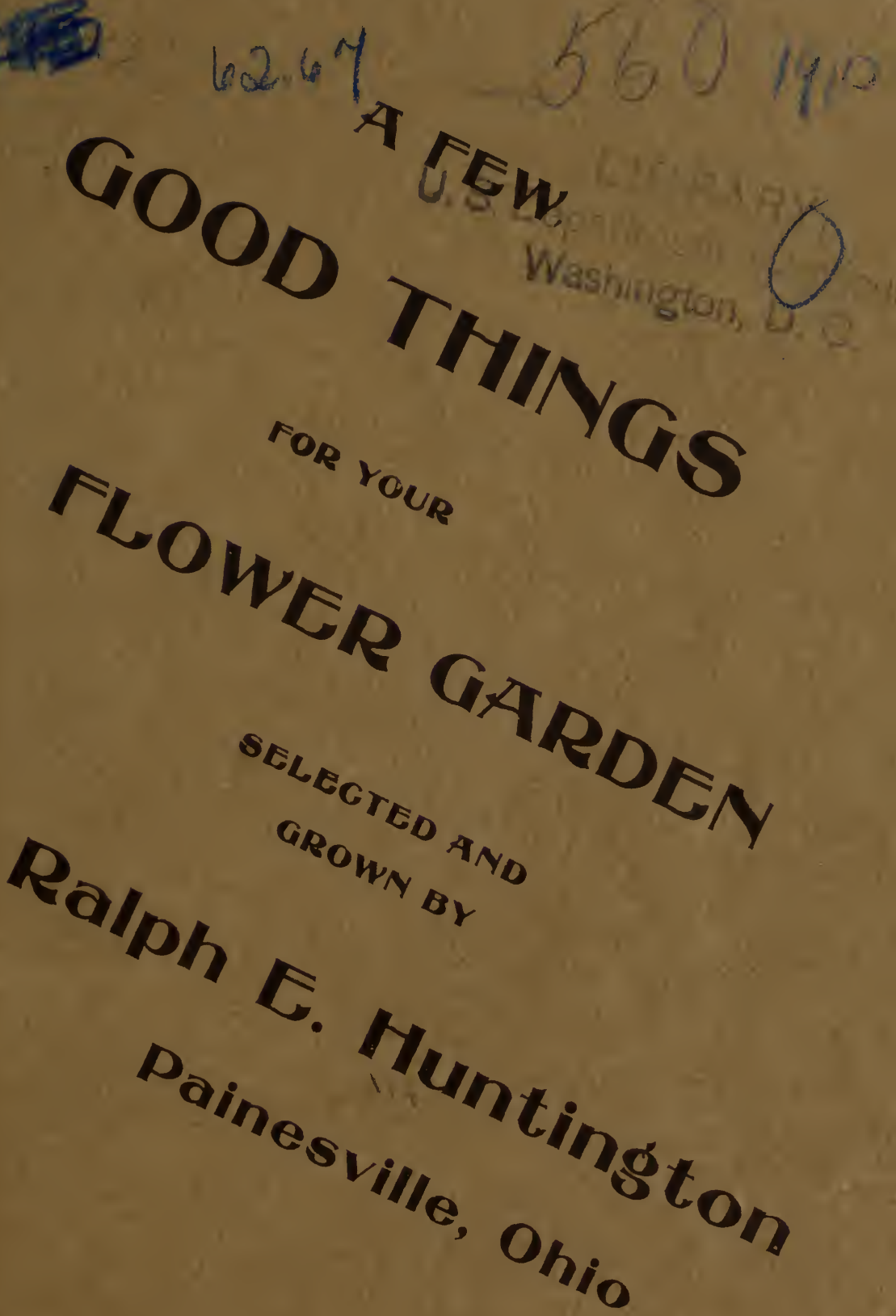


Your SugGess

With My Stock

Means

My Sugcess

In My Business 


\section{Ton the Uarresprantident}

In presenting this little list I wish first to express my thanks for the generous patronage and for the many kind letters of appreciation received during the past season.

For the benefit of those who did not see my '09 list a short description of my stock might be of interest.

I am especially proud of my asters, dahlias and gladioli. Not only are they leaders for the professional cut flower grower but they are particularly adapted to the home garden, being select seeds and bulbs of varieties picked from trials of hundreds. My perennials and other stocks of my own growing are just as carefully selected and handled. Such stock as I buy is all grown within three miles of me, enabling me to personally select specimens from thousands.

In listing varieties I have paid no attention to novelties as novelties. Sorts, whether new or old, if not up to the mark are thrown out. Very few of the high priced novelties will succeed in the hands of the average fancier. They are seldom well established and are usually propagated at very high pressure in order to wring all possible profit from them before the newness wears off. Low price is no reason for condemning a variety. To stand the test of time is really a recommend, provided the stock in question has been well grown. High price does not necessarily mean excellence. I have found at the cost of much time and more money, that all too often it means a slight difference in color, shape or habit, which really amounts to nothing.

I claim nothing wonderful for my offerings. I do claim, however, to offer splendid, strong stock and seeds and to see that you are successful with them.

Please do not consider our deal closed until you have secured satisfactory results. Whether your order amounts to 5 cents or $\$ 50.00$ I realize as a business proposition that my success depends upon yours and I am willing to take any amount of trouble to gain it for you.

I am neither the largest grower nor the oldest. I have my reputation to make. Send me a trial order, no matter how small and let me prove to you that I merit a share of your patronage. 


\section{ASTERS.}

Of my own growing. These, together with a few late additions, are the result of years of experience and seed selection with regard to growing for the wholesale cut flower trade. They are the very best seed from the beds which won such warm commendation from the hundreds of visitors who saw them this season. My sales were so large last season even at the high price set that I had not enough of some varieties to go around.

This season I gave my entire attention to seed and propagating, only retailing a few flowers at home. My plantings were larger and I am able to set a much lower price on seed that will come fully to the mark of last season if not a little better.

The following list with the addition of Mette's Queen of the market just about covers the cut flower situation.

Try them and follow the explicit directions sent out with each order. You will have larger and finer asters than ever before.

Early Wonder. Sown in April, blooms early July. Splendid extra early aster, comet type, long stem, good cutter. White, pink. 15c.

Semple's Late Branching, (2) Sept. The main crop aster. Plants under my system of cultivation will average 30 inches to 3 feet high, stem 20 to 30 inches, flowers 4 to 5 inches across. Colors, Snow White, Shell Pink, Rose, Deep Pink, Purple, Azure Blue and Crimson. The two last do not make the perfection or size of the others. Pk't, 10c.

Pink Beauty, Early August to September. A beautiful pale, blush pink, comes with the largest percentage of perfect flowers of any aster that I ever saw. A strong grower, from 24 to 30 inches high, good stem. Flowers as round as a ball, from $3 \frac{1 / 2}{2}$ to 4 inches. Never comes yellow centered. A very Compact, upright plant. Pk't, 15c. 
Royul Stripe, (4) Sept. A new aster and rather hard to describe. Light blue with a band of white around each petal. Those who saw it on my grounds this season compared it to a bunch of blue and white baby ribbon. Flowers average 4 to 5 inches. Stems 18 to 24 inches. It is of the branching type and makes a rather lower plant than Semples. Not a really dependable sort yet, shows rather too many poor flowers. With all it's faults it is a beauty and well worth growing. Pk't, 10c.

Lady Roosevelt, The largest plant and longest stem in cultivation. Many of the plants from which seed was taken stood 54 inches tall. Flowers averaged $3 \frac{1}{2}$ to 5 inches, very heavy, full round, incurved petals. A typical Chrysanthemum flowered aster. Color, bright Pink. I cut flowers this season with stiff, heavy stems, as long as 42 inches. Pk't, 25c.

Imperial, Early August to September. White, Lavender, Pink. Answers to description of Pink Beauty. Not so large in plant or flower and not quite so fine in shape. Pk't, 10c.

Early Branching, (8) About two weeks earlier than late branching. Only two colors, White and Rose. A splendid free blooming long stemmed variety. Not subject to yellow center. Pk't, 10c.

Royal Purple, (7) In bloom with Early Branching. A rather low growing, long stemmed aster, center well covered with wide incurved petals. Splendid deep Purple in color with a heavy band of green leaves showing just under the flower. A very desirable aster. Pk't, 10c.

Violet King, (1) Comes just after Royal Purple and continues till late in the fall. Immense flower of entirely distinct form. Large, broad, quilled petals, center being fantastically twisted and incurved, completely covering the crown. Flowers averaged this season 4 to 5 inches, with stems from 20 to 40 inches. Color soft pale Violet. Pk't, 10c.

Vick's Mikado, A very graceful and truly immense comet aster. It hasn't the staying qualities of the branching or of the Imperial type either in stem or flower but is is a beauty and coming in just before Late Branching it makes a fine addition to our list. Three colors, Rose, White and pale lavender Pink, I especially recommend the latter. Pk't, 10c. 
Lavender Gem (6) A delicate lavender aster of the comet type. The earliest true lavender. Medium size, long stemmed variety, not the best keeper in the world. Not so subject to disease as some. ' hose who have had trouble with yellows will do well to try this. Pk't, 10c.

The Crego, (3) This is a late aster, much resembling the comet in shape, but heavier, of stronger stem and a better keeper and sbipper. Considered by many professionals the very best late commercial cutting variety. My seed is grown by the originator, G. S. Crego, at Portland, Oregon. This aster is so late in blooming that it gives better results from seed raised in the West. White, Shell Pink, Rose, Purple. Pk't, 10c.

Vick's Cardinal, (5) Early August till fall. Bright Cardinal. An extra free blooming variety. Splendid bedder and a good cutting aster. I recommend this in place of Semple Crimson. Pk't, 10c.

\section{DAHLIAS.}

Many of the finest varieties especially in the lighter colored cactus and decorative dahlias are a distinct failure in the northern and middle states and more than 200 miles from the Atlantic seaboard. The following list is a survival of the fittest from over 500 varieties and will be found to do well wherever Dahlias can be grown at all.

They are carefully rogued of yellow centers and all undesirable traits. Those who have "no luck with dahlias" will do well to try them.

\section{(Cactus.)}

Aegir, Fine crimson, very free.

Countess of Lonsdale, Salmon Pink, earliest and most profuse.

Floradora, Dark velvety crimson, very free.

Kriemhilde, Delicate Pink, shading to deep pink.

Mrs. Charles Turner, Clearest Yellow.

Mrs. Freeman Thomas, Yellow, shading to light orange on tips.

Mrs. H. J. Jones, By far the best fancy cactus. Incurved portion of petals deep crimson, sometimes striped with white. Sometimes entire flower will be solid cream 
with other flowers on same plant solid red and others beautifully striped. 25c.

Standard Bearer, Brilliant crimson of fine form. Free.

Seigtried, Large cream white.

\section{(Decorative.)}

Black Beauty, Velvety Maroon, free.

Catherine Duer, Bright Scarlet. Splendid but rather shy.

Countess of Pembroke, Pearl Pink.

Claribel, Bright Purple, free.

C. W. Bruton, Finest yellow decorative.

Eloise, Red and white striped, rather dwarf plant.

Fire Rain, Cardinal red, splendid cutter.

Frank L. Basset, Deep royal purple, rather shy.

Jenne Charmet, A magnificent garden variety. Its size is somewhat against it for shipping. Flowers will reach $61 / 2$ inches on stiff wiry stems often 16 inches long Flower faint yellow at margin of petals, shading to pink and then lightening to white at the center. Very free and continuous blooming. 25c.

Lyndhurst, One of the best bright scarlets, fine cutter.

Nymphea, Clear shrimp pink, shading lighter toward center.

Oban, Deep pearl pink. 10c.

Mrs. Roosevelt, Giant class, enormous flowers of delicate pink.

Sylvia, White, shading to soft pink, splendid cut flower, free.

Sov. De. Gustave Douzon, Giant, a beautiful red, six to eight inch flowers borne on long stems well above the foliage. Extra fine. 25c.

Willian Agnew, Best blooming variety in reds. Has not the stem of Fire Rain or Lyndhurst but will do better than either in the north central states.

\section{(Show and Fancy.)}

A. D. Livoni, Old variety but the best clear pink to date.

Arabella, Sulphur and pink, edged white.

Arlington, Bright red, long stem.

Cuban Giant, Immense dark crimson.

Fascination, Rose pink with white tips.

John Bennet, Yellow, tipped red.

Majestic, Originated in Painesville, a seedling of Mr. Werner's. An immense flower of the giant class, clear yellow of fine form. Flowers are carried well above the plant on long, strong stems, carrying two or more flowers. An extremely fine cut flower. 25c. 
Miss May Lomas, White with deep lavender center.

Penelope, White with faint lavender center, finest cut flower. Philadelphia, A most striking variety. Cream with deeper shading toward center. An extremely free bloomer on long stiff stems. Slightly quilled, well rounded flower of great substance. A splendid dahlia. 25c.

Queen Victoria, (Mary D. Hallock), Pure deep yellow, finely quilled.

Remington, Pale pink, loosely built flower, very free.

Ruth, Another Painesville introduction. White, ends of petals tipped deep lavender pink. A splendid free blooming variety. Will stand early planting.

Wellesley, White, tipped deep purple.

White Dove, A very free blooming white.

Willie Austin, Generally clear amber, sometimes fawn colored flowers on same plant. A very handsome fancy dahlia.

\section{(Pompon.)}

Klien Domitea, Free blooming salmon b\&ff.

Little Beatrice, Delicate Pink.

Snow Clad, White.

Sunshine, Scarlet.

\section{(Single.)}

20th Century, Rosy crimson, white tips. Very large.

Gorgeous, Immense dazzling scarlet, excepting occasionally a pure white petal. A very striking variety and a fine cutter. 25c.

Wildfire, Rich scarlet.

White Cross, White.

President Viger, Collarette dahlia. Rich deep blood red, shading darker, with white collar. 25c.

Price, unless noted, $15 \mathrm{c}$ each; per doz. by mail postpaid, $\$ 1.00$; larger roots, by express, collect, $\$ 1.00$; per 100 , $\$ 7.00$. 


\section{GLADIOLUS.}

The following list comprises the very best for cutting purposes and are the varieties most largely used by the professional cut flower trade. I have priced them as cheaply as possible for good stock. Would advise where possible to order by express as I can send much larger bulbs.

\section{Two Splendid Gladioli.}

These originated with one of our Ohio growers and bave been on my place for three years. They are the most sturdy of their race that I have ever seen. Almost every bulb throws out two blossom stalks and I have seen as many as four good stems from one bulb this season. They are of uncompromising upright growth, even when dug this fall the old stalks stood as straight as a line of lath. Sometimes second stalks start out at an angle of 45 per cent but the first is unbending. Those of my readers who have grown heavier Childsii, Groffs and above all, any of the Blue Hybrids will appreciate this upright growth. These are offered to the retail trade for the first time this season.

Grenadier, Scarlet ground overlaid velvety orange. Lower petals each bisected by a narrow white band, running to a throat of gleaming mahogany. Upper petals silvered, the whole faintly mottled with tawny red. Edge of petals are slightly wrinkled, giving to the flower a ruffled appearance. It's gorgeous color, both front and back, makes it an ideal bedder as well as cut flower. Size large, spike compact and full. Substance extra good. Splendid keeper, multiplies at least twice. $12 c$ each, \$1.25 per dozen, \$8.50 per 100 .

Eighty, Compared with Grenadier, a slightly smaller flower, carrying a few more to the stalk. Deep scarlet with well defined narrow brown bands, running to a throat of purplish wine color. Upper petals correspondingly banded in faint silvery white. A very compact spike, splendid keeper. 8c each, 75c per dozen, \$5.00 per 100 .

(General List.)

America, An immense slightly flabby flower of clear lavender pink. A fine cut flower of strong growth. 10c each, $\$ 1.00$ per dozen, $\$ 7.00$ per 100 . 
Ceres, White, flaked purplish rose. A good companion for Brenchleyensis. $5 c$ each, 40 c per dozen, \$2.50 per 100. Eugene Scribe, Large flowers, deep rose, blazed carmine. $8 \mathrm{c}$ each, 75c per dozen, \$5.50 per 100.

Independence, A very good flower, deep pink. Very vigorous and extremely prolific. $7 \mathrm{c}$ each, 60c per dozen, $\$ 5.00$ per 100 .

Mrs. Frances King, Enormous wide open flower, of deep salmon pink, mottled darker. Its great size makes it rather loppy and it should be staked. A splendid cut flower and good keeper. Until sold out, 8c each, 75c per dozen, $\$ 7.00$ per 100 .

May, White ground, shot with deep pink, some dark, some lighter. A very good variety for medium priced cuting. 5c each, 40c per dozen, $\$ 2.50$ per 100.

Augusta, A splendid white with blue anthers. 5c each, 50c per dozen, \$3.50 per 100 .

Blanche, Pure white, faint rose markings. Largest white to date. 12c each, \$1.25 per dozen, \$8.50 per 100 .

Brenchleyensis, An old sort but still a splendid variety for medium priced massing and cutting. 25c per dozen, $\$ 1.75$ per 100 .

Saratoga, Large flaming orange scarlet. An extremely good variety. 10 c each, $\$ 1.00$ per dozen, $\$ 7.00$ per 100 .

Siboney, Slaty gray, marked and mottled darker. 5c each, 50c per dozen, $\$ 4.00$ per 100 .

Taconic, Bright lively pink, flecked and striped with shades of the same color, lightening to faintest blush in the throat. Of healthy, strong growth. I recommend this very highly. $10 \mathrm{c}$ each, $\$ 1.00$ per dozen, $\$ 7.00$ per 100 .

Pink and White shades in mixture. A mixture of about 30 of the best named varieties of these shades on the market. 60c per dozen, $\$ 4.50$ per 100 .

Mixture of Red Shades with white throat. Splendid red mixture, mostly Childsii. 40c per dozen, $\$ 3.50$ per 100 .

Blue Hybrids in mixture. Liable to come with crooked stem. Blue gladioli are well enough to fill out a collection but for cutting or bedding I do not recommend them. 8c each, 75c per dozen, \$5.50 per 100.

Older Varieties in mixture of all colors. A very good low priced mixture of all sections, Groff, Childsii, Lemoine, etc. 30c per dozen, $\$ 2.00$ per 100 . 


\section{METTE'S SEEDS.}

On account of many requests for seeds and plants other than my specialties I have decided to list the few following. I have used the same care in buying seeds that I do in raising them.

The following seeds are the product of the Henry Mette Co., of Quedlinburg, Germany. In the fine cut flower and greenhouse trade this firm is about the last word in regard to Verbenas, Stocks, Pansies, Petunias, etc. They exhibit at every large exhibition in Europe and it was the extremely favorable notices in connection with these exhibits that first led me to try their seeds. For germination, trueness to type and color and general results I have found them the very best that I ever tried.

\section{ANTHIRRINUM, (Snapdragon),}

Showy half hardy perennials, generally treated as annuals. Sow outside in early spring. Sometimes they will stand over winter with protection but will do better if sown every year.

Romeo, Deep rose, shaded pink, yellow spotted lip. Tall. 10c. Delila, Carmine, yellow and white. Giant. 10c.

Golden Queen, Large flowered pure yellow. Dwarf. 10c. Dwarf, Mixed. 5c.

Tall, Mixed. 5c.

\section{ASTERS.}

A few very good asters that were seen on our grounds this season. From Mette's growing. Splendid garden garden varieties.

Japanese, A curiously shaped quilled and waved variety about 14 inches tall, well branched, colors are very strong and attractive, an extremely good bedder, stays in bloom and stands weather very well. Good stem. Crimson, flesh, cannibar carmine, rose, mixed. Pk't 10c. 
Hohenzollern, Early. A beautiful delicate colored variety of the comet type. Blooms early July. Rather dwarf with us. Full round flower. Limp stem. White, white shading to rose, rose, purple, lavender, mixed. Pk't 10c. Hohenzollern, Late. Blooms with Early Branching. Longer stem but rather limp. Larger flower, rather flat and loosely built. White, rose, purple, mixed, Pk't, 10c. Silvery lilac, a beautiful color, Pk't, 15c.

Ostrich Plume, The finest midseason Comet aster yet introduced. Immense size. Equals some of the Chrysanthemums. For cut-flowers cut when about half open and allow to develop in a cool place. Rather limp stem. White, pink, purple, carmine, light blue or lavender, mixed. Pk't, 15c.

Peony Perfection, Most perfect in form, very double, compact growth. Rather small in flower, very easy to handle. A splendid little cutter. Firey scarlet and white, rose and white, violet and white, brilliant lilac blue, delicate rose. Good stem. Pk't, 10c.

Pompon Imbricated, August. A free blooming, symmetrical plant, simply covered with perfectly solid flowers about $1 \frac{1}{2}$ inches in size down to $1 / 2$ inch and every one perfect. Good stem.

Ruby and White, A very striking half dwarf aster. Deep crimson striped and marked snow white in center of petals. 75 per cent of the flowers were as good as the half tone, which comes from Mette. Plk't, 15c.

Yellow, Fancy aster with an immense quilled center of yellow edged with a frill of wide guard petals of sulphur. Pk't, 10c.

Queen of the Market, A well known early flowering aster, early July. Flowers of good size, densely double and borne on long stems. An exceedingly good cutter. I grew seed of this for some years but could not improve on Mette. White, rose, purple, shell pink, lavender. Pk't, 10c.

Single Chinese. Very effective in beds and borders. Mostly of Shasta Daisy shape, many different colors, mixed. P'⿳亠丷, 10c.

\section{BALSAM (Lady's Slipper).}

An old favorite of easy culture, producing gorgeous masses of brilliant colored flowers.

Exquisite, Faint creamy buff ground, marked and splashed with apricot, truly exquisite. 10c. 
Camelia Flowered, White, apricot, mixed. 10c. Defiance, Mixed. Giant Camelia flowered. 10c. Camellia Flowered. Common strain. White, scarlet, lilac, rose, purple, red. 5c.

\section{CANDY TUFT.}

A most useful hardy annual.

Giant Empress, Immense heads of pure white. 10c. Dumnet's Crimson, Finest crimson. 10c. Little Prince, Dwarf. 5c. New Carmine, 5c.

\section{CELOSIA PLUMOSA (Cockscomb).}

Aurantiaca, Orange yellow.

Kermesina, Crimson.

Thompsonii, Mixed, yellow, scarlet, cream, etc. Pk't, 5c.

CELOSIA CRISTATA, (Dwarf Cockscomb),

Splendid border. White, crimson, yellow, rose, mixed. Pk't, 5c.

CENTAUREA IMPERIALIS (Sweet Sultan).

Beautiful sweet scented flowers. Fine for cutting, sow very early.

Improved Imperial, White, yellow, lavender, mixed. 10c.

CENTAUREA CAYNUS (Bachelor's Button).

Marguerite, White. 5c.

Kaiser Wilhelm, Blue. 5c.

Mixed, 5c.

CENTAUREA GYMNOCARPA (Dusty Miller).

A low growing plant with silvery gray leaf. Fine for border. .5c.

\section{COSMOS.}

A strong growing plant with very handsome foliage. The old stand-by for late fall cutting.

White, Pink, Crimson, Early dwarf mixed. Tall late mixed. 5c. 


\section{DELPHINIUM (Annual Larkspur).}

Dwarf Rocket, Mixed. Fine double. 5c.

Tall Rocket, Mixed. Fine double. 5c.

Tall Branching, Old fashioned single. 5c.

\section{DLANTHUS (Garden Pink).}

Grandiflorus Striatus, Extra large. White, striped dark crimson. Double. 10c.

Salmon Queen, Brilliant salmon. Very distinct and charming. Double. 10c.

Cyclope, Large dark rose, crimson zone around eye. Single, 5c.

The Bride, White, purple center, very handsome. Double. 10c.

Queen of Holland, New large flowered. Pure white. Double. 10c.

Fringed, Double mixed. 5c.

\section{IPOMOEA.}

Climbers of rapid growth, beautiful and varied flowers. For cover they are invaluable on porches, trellises, walls etc.

Imperialis, (Japanese Morning Glory.) 5c.

Coccinea, (Star Ipomoea), Small scarlet flowers. 5c.

Rubra Coerulea, Immense flowers of bright sky blue. .10c. Grandiflora Superba, Sky blue and white. 10c.

Grandiflora Mexicana, (Moonflower.) $10 c$.

Superba Alba, Common white. 5c.

\section{MIGNONETTE.}

Very rapid growth, rather dwarf, delicately scented. Does best during cool months. Plant either very early or very late or both for succession.

'True Machet, Thick dark green leaves. Gray flowers. 5c. 1900, Cream colored flowers, richest fragrance. 10c.

Golden Queen, Light golden yellow. 5c.

Ruby, Largest size, intense red. 5c.

Mixed, 5c. 


\section{MARVEL OF PERU (Four O'clock).}

A well known garden favorite. Is gaining in popularity as a border for walks and drives, for which it was used very generally in Cleveland and vicinity this past season.

Variegated Foliage, In rich contrast to the bright colored flowers. White, crimson, red and white. 10c. Tall, Yellow, rose, crimson, lilac, mixed. 5c. Dwarf, Yellow, yellow and white. 5c.

\section{NASTURTIUMS.}

For ease of culture, brilliancy of coloring and duration of bloom nothing excels the Nasturtium. Give a well drained sunny position, soil must not be too rich. Sow seed early and about 2 inches apart. In a few weeks there will be an endless profusion of gorgeous blossoms. Varieties offered below are the very best of their kind and color.

\section{(Tom Thumb.)}

Dwarf compact rounded growth. Fine for edging.

Auxora, Bright chrome yellow, veined purplish carmine. 5c. Beauty, Glowing orange with scarlet markings. 5c.

Cloth of Gold, Golden yellow leaves, brilliant scarlet flowers. A beautiful and striking combination. 5c.

Chaneleon, Flowers of diversified coloring. Many different colors and brilliant markings on same plant. 10c.

Deep Scarlet, Bright vivid scarlet. 5c.

General Jacqueminot, Dark green leaves. Glowing crimson scarlet flowers. 5c.

Golden Queen, Very dwarf, fine form. Small, light yellow green leaves. Rich orange yellow flowers. 10c.

Rudolph Virchow, Fine form, very free. Soft pink flowers. $10 c$.

Pearl, Fine light cream colored flowers. 5c.

Mixed, 5c.

(Ivy Leaved.)

Foliage with marked resemblance to English Ivy.

Flamingo, Tall, dark green leaves, orange scarlet. $10 \mathrm{c}$.

Golden Gem, Golden orange yellow. tall. 10c.

Golden Butterfly, True dwarf ivy leaved. Very early flowers. Golden orange.

Dwarf, Ivy leaved, mixed. 10c.

Tall, Ivy leaved, mixed. 10c. 


\section{(Variegated Foliage.)}

Every leaf is marked with yellow, white and green in different combinations. Plant rather thickly. They are new and not well established. Sports can be easily removed.

Tall, mixed. 10c.

Dwarf, Mixed. 10c.

Lobb's Tall, (the old variety.)

Chameleon, Different colored flowers on same plant. 5c.

King of the Blacks, Dark leaves, deep crimson flowers. 5c. Pearl, Creamy white. 5c.

Rose, A beautiful shade of ruby rose. 5c.

Scarlet, Glowing vermilion. 5c.

Nankeen Yellow, Clear yellow, few veins. 5c.

Velvet Foliage Crimson, A beautiful variety. 10c.

Mixed California Giants, A splendid mixture of giant flowered varieties. 10c.

Mixed Lobb's Tall, 5c.

Marigold, Favorite free flowering annuals of easy culture.

Eldorado, Large imbricated and extremely double. All shades of yellow. 5c.

Lemon Queen, Soft lemon yellow flowers. 10c.

Prince of Orange, Intensely double flowers of a rich deep golden orange. A fine contrast to Lemon Queen. 10c.

Gold Striped, Dwarf, very double, brownish red, striped golden yellow. 10c.

Legion D'Honneur, Dwarf, golden yellow, marked crimson. $5 c$.

French, Dwarf striped, mixed. 5c.

African, Tall double, yellow shades, mixed. 5c.

\section{PANSIES.}

Too well known to require description. For summer blooming sow in early spring in a cool spot, somewhat shaded. For spring blooming sow in the fall. Enrich soil with thoroughly rotted manure. Varieties listed below are selected from Mette's best. Mette leads the world in Pansies.

Mette's Triumph of the Giant, Robust growth. Compact round plant. Healthy heavy foliage. Long stems. The flower petals are exceedingly broad and cover each other in such a manner as to make the flower appear almost double. Border of petals on most flowers is curiously undulated and curled, giving them a most 
striking and very peculiar appearance. Very new and rare tones of red and brown as well as other combinations of the more common colors. Flowers of this blend have been seen at every large European exhibition since 1904 and it is constantly improving. Pk't, 50c.

Cassiers' Superb, All either three spotted or five spotted. An extremely good strain. Pk't, 15c.

Golden Queen (Trimardeau), Pure yellow, fine. Pk't, 15c. Cardinal (German), Immense bright red. Pk't, 10c.

Black Prince (German), Large flowered velvety black. Pk't, 10c.

Peacock (German), Peacock blue with white edge. Pk't, 10c. Indigo Blue (Trimardeau), Very fine deep blue, giant. Pk't, 10c.

Snowflake (Giant Trimardeau), Clear white, fine. Pk't, 10c. Prince Bismarck (Trimardeau), Gold bronze, marbled. Pk't, 10c.

Light Blue (Trimardeau), A clear light blue. Pk't, 10c.

\section{PETUNIA.}

Few plants equal the Petunia for either bedding or house culture. They commence flowering early and continue until stopped by frost. I list no double sorts. They do not come more than 25 per cent true. If wanted I can furnish them in fine variety but I do not recommend them for garden culture. Named varieties in singles will sport more or less. Mette's come truest of any that I ever saw. The weaker seedlings will make the best flowers.

Giants of California, Mixed. Nearly all flowers ruffled and fringed. Immense size, great variety of coloring, deep throats of yellow, black, white, green or maroon, runing off into intricate veins of gorgeous colors. Pk't, 15c.

Hybrida Grandiflora, Large flowered single. Immense flowers.

Alba, Large white. 10c.

Atro Purpurea, Deep purplish crimson. 10c. Aurora, Light rose, veined crimson. 10c.

Brilliant, Beautiful rose. 10c.

Elegans, Deep blood red, white throat. 10c. Steel Blue, Very effective. 10c.

Admiration, Deep violet blotched white. 10c. 
Rosy Morn, A beautiful variety for edging. Rather dwarf, of compact growth. White throat, edge flushed soft rose. Pk't, 10c.

Howard's Star, A magnificent variety, free blooming, crimson maroon with a well defined five pointed star of blush white. An early bloomer and continues till frost. Pk't, 10c.

Magnifica, A richly colored mixture of free small flowering petunias of dwarf, compact habit. Color ranges from white to lilac, rose, carmine, crimson, and purple, with white or light colored throat, partly bordered, starred or marbled. A truly magnificent variety. Pk't, 15c.

Petunia Hybrida, The common old standby.

Gen. Dodds, Darkest red, fine. 5c.

Erforda, Brilliant rose, white throat. 5c. Mixed, A fine mixture of light and dark colors, blotched and striped. Pk't, 5c.

\section{SWEET PEAS, (Spencer Type.)}

No Sweet Pea equals this family either in size, length of stem, color or form, which is distinct in having the edges of both standard and wings beautifully fluted or ruffled. Often giving four flowers to the stem and almost always three.

Princess Alice, Pale lavender.

Princess Catherine, Black seeded white.

Dainty, White with pink edge.

Mrs. Joseph Chamderlain, Rose on white ground, flaked.

True Countess Spencer, Soft rose-pink, deeper at outer edges.

Spencer Mixed, Contains many that are selling at 1c each.

Pk't, 10c. 1/2 oz. 30c. oz. 50c.

\section{(Unwin Sweet Peas.)}

Same type as Countess Spencer but not quite so large.

Gladys Unwin, Pale pink.

Phyllis Unwin, Rose-pink.

Nora Unwin, White.

Frank Dolby, Lavender.

E. J. Castle, Carmine rose.

Pk't, 10c; 1'́2 oz. 20c; oz. 35c. 


\section{(Grandiflora.)}

Best types of the kind you have always grown.

\section{White-}

Dorothy Eckford. Profuse, early.

White Wonder. Large size, 4 to 8 on a stem.

Shasta, Ivory. Very vigorous, long season of bloom.

Yellow-

Hon. Mrs. E. Kenyon. Primrose, giant flower.

Mrs. Collier. Primrose.

Stella Morse. Apricot.

\section{Pink-}

Golden Rose. Primrose, flushed pink.

Blanche Ferry. Pink and white.

Agnes Eckford. Soft pink, large size.

Prima Donna. Bright rose.

Apple Blossom. Shaded in deep pink and soft rose on white.

Her Majesty. Deep rose.

Crimson and Scarlet-

King Edward VII. Large flower, crimson scarlet.

Midnight. Deep maroon.

Queen Alexandria. Intense scarlet, does not fade.

Blue and Lavender-

Countess of Radnor. Clear lavender.

Mrs. Geo. Higginson, Jr. Sky blue.

Romolo Pizzani. Violet blue.

Captain of the Blues. Navy blue.

Variegated-

America. Striped red on white ground.

Helen Pierce. Mottled bright blue on pure white.

Aurora. Flaked orange on creamy white.

Gray Frair. Purple on cream white.

Ex. Early -

Christmas. White.

Christmas. Pink.

Sunbeams. Primrose.

Mont Blanc. White, extremely early.

Mixed Grandiflora-

A fine mixture of all the foregoing of this type together with many new and old varieties not listed, a very fine mixture. Price, all Grandiflora mixed or named. Pk't, 5c; oz. 10c; 1/4lb. 15c; 1b. 45c. All prices on Sweet Peas are by mail delivered. 


\section{PHLOX DRUMMONII, GRANDIFLORA,} (Annual Phlox.)

A splendid brilliant garden annual. It will grow and thrive anywhere if given a sunny position.

Snow white, white with purple eye, crimson purple with white eye, crimson purple striped white, crimson, mixed. Pk't, 10c.

PORTULACCA, (Sun plant or Moss rose.)

One of the finest hardy annuals. Does best in light loam or sand and must be in sunny position. Flowers of richest color. Fine for low massing.

White, yellow, carmine striped, crimson, flesh, mixed. 5c.

\section{POPPY.}

Sow as early as possible and where they are to remain. They will not stand transplanting. To get best results thin to 3 or 4 inches.

Mette's Select Shirley, An extra fine strain. Single and semidouble, and range in color from white to pink, crimson, flesh, rose, carmine, crimson, and blood red, striped and edged with white. 10c.

Burbank's Silver Lining, An extra fine strain. 10c.

Daneborg or Danish Cross, A very showy variety. Large flowers of brilliant scarlet with a white spot on each petal, forming a white cross. 5c.

Glaucum (Tulip Poppy), Bright dazzling scarlet. 10c. Peony Flowered, Large double, mixed, all colors. 5c.

Miss Sherwood, Delicate pink. Fine. 10c.

Mixture of all the above. 10c.

\section{SALVIA, (Scarlet Sage.)}

Sow early indoors give it plenty of time. It is very slow to germinate. Too well known to describe.

Splendens, The well known tall variety. 10c.

Fireball, Very dwarf and compact. Above two feet tall and the same in diameter. A veritable ball of fire. 20c.

Bonfire, Splendid dwarf variety, more erect than Fireball. 15c.

Farinacea, Violet blue. 10c. 


\section{SALPIGLOSSIS, (Painted Tongue).}

Fine hardy annual, flowering freely from July to October. Funnel shaped flowers veined with purple, crimson and yellow. A splendid cut flower. Do not cover seed but shade from hot sun.

Rose, violet, scarlet, brown with gold, light blue with gold, mixed. 10c.

\section{STOCKS.}

One of the most popular hardy annuals. Sown in March or April they commence flowering in July. Mette's Stocks are used by professional florists throughout the world.

Perpetual Giant Perfection (Princess Alice). White, brilliant lilac, golden chamois, light blue, apple blossom, mixed. 10c.

\section{SWEET WILLIAM, (London Tufts.)}

Well known free flowering hardy perennials. Sow in September, they will flower in the spring.

Mette's New Giant Flowered, mixed. $15 \mathrm{c}$. Perfection, Mixed, white margined varieties. 5c. Dunuet's Crimson, 5c.

\section{VERBENA.}

A very fine strain of a well known flower. They are large, as large as I ever saw, but I would not call them giants. A better strain cannot be bought.

White, blue, pink, purple, scarlet, blue with white eye, mixed. 10c.

\section{ZINNIA.}

Most brilliant and showy of annuals and a general favorite.

Giant double white, scarlet, golden yellow, crimson, rose, violet, tall mixed, dwarf mixed. 5c. 


\section{Roses and Hardy Plants}

I am in position to furnish the following list in plants that are as near to perfection as they can be grown. Some of these I grow, most of them I buy. Within five miles of me are located no less than fifteen growers. I buy from no single one of them but wherever I can get the best stock. To customers who are known to me I will ship "on suspicion" any plants wanted. To others the rule holds the same in so far as the privilege of examining goes. If plants are not perfectly satisfactory return and get your money. They are selected as the best from thousands and will satisfy the most exacting. I would be pleased to quote prices on anything in the nursery line, Fruit Trees, Hardy Ornamental Shrubs, Climbing Vines, Small Fruits, etc. I can save you money.

\section{HYBRID PERPETUAL AND CLIMBING ROSES}

The following list just about covers the ground in best hardy roses. For those in the northern states who admire the tea roses I can furnish in own root plants, a splendid list at about the same price as for any of the more common bedding plants. These will furnish a fine lot of flowers and with plenty of protection they may pull through. If they do not they will cost no more than other bedding plants.

We can furnish standard roses grafted on four foot stems, at $75 \mathrm{c}$ each.

American Beauty. Large, globular, deep rose color; delightiul fragrance.

Anne de Diesbach. Carmine, a beautiful shade; fragrant, a superior garden sort.

Baby Rambler. A hardy ever blooming dwarf rose. Of dense growth, in flower from June until frost; a fine sort to plant on the border of a rose bed.

Baltimore Belle. Pale blush, nearly white and very double. Flowers borne in large clusters. A climbing variety and best trained on a trellis. June. 
Baroness Rothschild. Light pink and of symmetrical form. Very beautiful, but of rather dwarf habit.

Clio. Flowers large, borne in clusters, globular form, fleshcolored shaded rosy-pink in the center. Robust habit and good foliage. One of the finest roses.

Dorothy Perkins. A pink climbing rose of great merit. A cross between Crimson Rambler and Wichuraina. Its foliage is similar to the Wichuraiana. Flowers produced in immense clusters and are of the most beautiful shell pink color. Should be trained to a support.

Eugene Furst. Velvety crimson shaded deeper in color. Large, fragrant flower of good shape. One of the best dark colored varieties and a good late bloomer.

Coquette des Alps. Pure white flowers in clusters. A medium grower and free bloomer.

Crimson Rambler. A remarkable rose now well-known. Flowers borne in pyramidal panicles. Of a vivid crimson color and enduring. Of climbing habit and should be trained.

Frau Karl Druschki. It is perfectly hardy everywhere and a most vigorous grower, throwing up enormous shoots which are covered with snow-white blossoms. Although there are many so-called white roses, before the introduction of this variety, we did not have a pure, snowwhite rose. A grand rose and one of the best novelties in recent years.

General Jacqueminot. Brilliant crimson, large, and extremely effective. Fragrant and a free bloomer.

John Hopper. Bright rose with carmine center. A profuse bloomer and standard sort.

Mad. Geo. Bruant. A cross between Rugosa and a Tea Rose. Flowers white, in clusters, and delightfully fragrant. Beautiful foliage and a perpetual bloomer.

Magna Charta. Pink, suffused with carmine; full and of good shape. Foliage and wood light green with darker colored spines. A fragrant, excellent rose. Valued for forcing.

Margaret Dickson. A fine variety with large green foliage. Flesh-colored flowers, petals shell-shaped and of great substance.

Marguerite de St. Amande. Bright rose, very beautiful in the bud state. This variety bears fine bloom in autumn.

Marshall P. Wilder. Bright cherry carmine, very fragrant and a free bloomer. Large size, good form, and an all around superb rose. 
Mrs. John Laing. Clear pink, fragrant, large flowers produced on long stems. Flowers continuously in the open ground and also a fine forcing rose.

Crested Moss. Deep pink colored buds, surrounded with a mossy fringe. The beauty of this and all Moss Roses is the bud, which for boquets is invaluable. June.

White Moss. Pure white and very large; fragrant. June.

Red Moss. Deep red, very large and beautiful. June.

Salet Moss. Clear rose color, of vigorous habit and a very free bloomer. June.

Paul Neyron. The largest-flowered rose in cultivation. Flowers deep, clear rose, exceedingly fragrant and a profuse bloomer.

Prince Camille de Rohan. Deep velvety crimson; large, moderately full. A splendid rose.

Persian Yellow. A free grower, with small, bright green foliage. Attractive, medium-sized, double yellow flowers, which are produced on the previous season's growth.

Pink Rambler. Foliage, form of flower, and climbing habit identical with Crimson Rambler, but the flowers are of a soft pink color. Requires a support.

Prairie Queen. Bright rose color, large, and compact. A climbing rose. June.

Soleil d'Or. One of the best varieties from France. Fine, large yellow flower shaded with orange. Very fragrant. A fine novelty.

Ulrich Brunner. Brilliant cherry red, the best variety of this color. Flowers of fine form and carried well on the plant. A vigorous grower.

White Rambler. A climbing variety of the Crimson Rambler type, but the flowers are smaller and pure white.

Yellow Rambler. The only hardy yellow climbing rose. Similar to the preceding except in color.

$35 c$ each; $\$ 2.50$ per 10; $\$ 20.00$ per 100.

I can furnish for May delivery plants of Salvia, Verbena, Asters, Pansies, Petunias, single and double, double in bloom, Ipomoea, Centaurea Gynnocarpa, Celosia, and Dahlias, Cannas in variety, Heliotrope, Geraniums, etc. Please write for prices on your wants. 


\section{HARDY PHLOXES.}

Among the perfectly hardy perennials nothing is of more importance than these. They will succeed anywhere and in almost any position and will flower freely for many years without attention, yet a little cultivation will be found to improve them.

Trench for planting about 20 inches, put plenty of well rotted manure in bottom then fill with top soil and manure about equal mixture. Mulch with old loose manure each year. We mulch in the fall and rake off in the spring. Set about 18 inches apart and water freely. Split about every three years into about three clumps and reset.

Athis. Tall; dark stemmed. Light salmon, violet eye.

August Revere. Salmon-red, dark eye.

Charlotte Saisson. A plaid effect of white and crimson.

Aglue Adanson. Immense flowers, snow-white, with red eye. 25c.

Coquelicot. A glowing orange red with violet eye. 25c.

Lclaireur. Purple-crimson, light aureole.

Eiffel Tower. A strong growing, large trussed sort; flesh pink with red eye. 25c.

Etna. Large flowers, orange scarlet with maroon eye.

Eugene Scott. Full heads of large flowers; white heavily suffused lilac, fading to porcelain blue; carmine eye.

Flambeau. Scarlet, overlaid with crimson, dark eye.

Gruppenkonigin. Delicate pale rose-mauve, with claret-red eye. Effective and showy. 25c.

Henri Murger. Big as a dollar; white, with extensive carmine center. 25̃c.

Jean Bart. Light rose, with cherry-red eye.

Josephine Gerbeau. Fine large trusses of white, with a central blotch of pale carmine.

La Soleil. Bright magenta-salmon, light halo. A pretty pink effect.

Lothair. Carmine-pink, with deep crimson eye.

Miss Lingard. Longest spikes of any Phlox-blooms from the ground up. Waxy white, with lavender eye.

Mme. Paul Dutrie. Delicate lilac-rose in shade like a soft pink Orchid; flowers very large, borne in immense panicles. 25c.

Mme. P. Langier. A dazzling pure crimson; one of the choicest dark reds. $25 c$. 
Mr. Gladstone. Large flat flower, tender rose with light red eye.

Pantheon. The peerless pink. Extra large, always flat flowers of salmon rose.

Prime Minister. Intense velvety crimson center, graduating outward into white.

Princess Louise. Medium sized white flower, with a little rose eye. Very symmetrical and dainty.

Prof. Schlieman. Ornamental red-stemmed foliage; very brilliant with shapely panicles of rose-lilac flowers. Late.

Purity. A strong growing white. 25c.

Rheingau. An ideal bedding sort, with large truss of pure white and faint pink markings at base of petals. 25c.

Snowflake. Good flower of snowy white.

The Pearl. A standard, pure white.

Virgo Marie. Unblemished white, rooty and vigorous.

Von Hochberg. The ideal crimson; the richest of its color.

25c.

Unless noted, 15c each; \$1.50 per dozen; by express, 10c each; $\$ 1.00$ per dozen.

\section{PEONIES.}

The queen of spring. Splendid for bedding or for massing in shrubbery border. Cultivation is very simple: Good rich deep soil and plenty of sun and water. They are perfectly hardy anywhere, requiring no protection in most severe winters and once planted will take care of themselves, increasing in beauty each year. Do not plant too deeply, cover crown about two inches.

Agida. Violet-red, semi-double.

Alba Sulphurea (Mont Blanc). Light sulphur-yellow, changing to white as flower becomes older. 50c.

Anemoneflora. Large; pale rose with buff center.

Beauty Francaise. Blush guards, buff center.

Canariensis. Flesh white, with rich canary center. 50c.

Couronne d'Or. Very late. Good sized flowers of creamy white, sometimes flaked carmine at center. $\mathbf{7 5 c}$.

Delache. Tall; immense globular heads of crimson-maroon. Dorchester (Richardson). Pink. One of the latest to bloom. Decidedly dwarf, compact grower; flower very full and double, in color about the shade of La France Rose. 50c; $\$ 4.50$ per dozen. 
Duchess de Nemours. Large and full; the most nearly pure white. $75 c$.

Duchess de Orleans. Large and compact, guard petals closely overlapping center. Rosy lake, with incurving salmon center. Late.

Duke of Wellington. Large, creamy white.

Edward Andre. A magnificent dark bedding Peony. Very large globular flowers of highly varnished mahoganyred, ultimately opening out to Anemone shape and revealing a gorgeous collar of gold. $50 \mathrm{c} ; \mathbf{\$ 5 . 0 0}$ per doz.

Felix Crousse. Late. Large, round heads perfectly double; deep crimson, marked with cardinal at base of petals. $\$ 1.00 ; \$ 10.00$ per dozen.

Festiva Alba. One of the best ordinary whites.

Festiva Maxima. About the largest and undoubtedly the most popular Peony of them all. High built flowers borne on long, stiff stems; the purest white, inner petals slightly tipped carmine. Early. 35c each; $\$ 3.50$ per dozen.

Francois Ortegat. Tall growing, with long stems; flowers of good size and shape, deep claret-maroon.

Hercules. A magnificent bedder-foliage concealed by bloom. I Loose globular heads open out to Anemone shape, 8 inches across. From bright rose to blush white, with thick collar and center of deepest yellow. $35 c ; \$ 3.50$ per dozen.

Humei. Pure, bright, deep rose; vigorous grower, one of the best late blooming varieties.

Isabelle Karlitzky. Delicate rose, very large and full.

Jeannette. Mauve pink guards, buff center.

Jeanne d'Arc. A choice variety notable for its exquisite perfume and other good cutting qualities. Guards pale lilac-pink, with full tufted center of sulphur. $\mathbf{7 5 c}$; $\$ 7.00$ per dozen.

Jules Calot. Bright pink fading to flesh.

Lady Lconora Branwell. Silvery rose.

L'Eclatant. Broad full flower, purplish-crimson; the best of its color.

L'Esperance. Deep rose with crinkly, white tips; extra large and fine; the earliest large pink.

Louis Van Houtte. Brilliant, velvety cerise-red.

Mad. Breon. Flowers, outside flesh, center lemon; occasionally carmine tipped, when first open; entire flower gradually changing to pure white.

Mad. Calot. Large, convex flowers, blush white with salmon shadings. 
Mad. Lebon. Valuable late red. Flowers ball-shape, very rich cherry-rose. $\mathbf{7 5 c} ; \mathbf{\$ 7 . 0 0}$ per dozen.

Magnifica. Magnificent rounded flowers of flesh white rising to cream. 35c; $\$ 3.50$ per dozen.

Marie Lemoine (Calot). Dwarf, extra late, and very scarce. White, faintly tinged chamois. \$1.00; \$10.00 per doz.

Mary Stuart. Blush, bleaching to pure white. 50c; $\$ 5.00$ per dozen.

Meissonier. Deep velvety cardinal, violet tipped. Flowers large and high built, with twisted and imbricated petals. 75c; $\$ 7.00$ per dozen.

Modeste Guerin. Brilliant carmine-rose, with a high and stiff center full of rosy-pink petals. 35c; $\$ 3.50$ per doz.

Mons. Jules Elie. The peerless pure pink. Broad, reflexing guards with a high pyramidal body of semi-quilled petals converging to an apex. One of the largest, handsomest and most lasting cutting sorts in existence. $\$ 1.00$.

M. Irrelage. A splendid full petaled globular head; vivid crimson. 75c; $\$ 7.00$ per dozen.

M. Thiers. Bright magenta, with full feathered center.

Mrs. Lowe. The earliest white. 50c; $\$ 5.00$ per dozen.

Officinalis Rubra fl. pl. Rich deep crimson; very early and one of the best of the dark colored varieties.

Officinalis Rosea. Earliest pink. 35c; $\$ 3.50$ per dozen.

Prince de Galles. Cup-shaped; purplish crimson.

Princess Mathilde. Broad, full flower; delicate rose, flushed salmon.

Pulcherrima. Remarkably free bloom, habitually in close clusters. Guards blush, the creamy interior merging into a purple flaked center of rose. $35 \mathrm{c} ; \mathbf{\$ 3 . 5 0}$ per doz.

Queen Victoria. The broad guard petals are a pretty blushwhite; center slightly edged pink. Large.

Reevesii. Warm pink and buff, with creamy white reverse.

Richardson's Perfection. Large flowers; light flesh with white center. \$1.00; \$10.00 per dozen.

Rosea Plenissima Superba. A superior double red sort, full centered and massive; bright crimson.

Rubra Superba. Very tall and strong, with long, stiff stems and elegant dark red flowers. 50 ; $\$ 5.00$ per dozen.

Rubra Triumphans. Early. A satiny-finished, intensely rich crimson; sweetly fragrant.

Sydonia. Deep lilac-rose, with lighter center. 
Triumph de Grande. A low, bushy bedding sort, literally covered with broad clusters; the prevailing white prettily variegated with sulphur, pink and carmine. $35 c ; \$ 3.50$ per dozen.

Triomphe de Paris. Outside white, center sulphur-yellow. Unless noted, 25c each; $\$ 2.50$ per dozen; $\$ 18.00$ per 100 .

\section{PINIKS (Hardy Garden)}

Without the spicy fragrance of the hardy Pinks a garden is incomplete; and their perfect form and rich coloring make them great favorites for summer bouquets.

Essex Witch. Delicate pink, finely fringed.

Her Majesty. Very large and purest white.

Homer. Rich rosy red with dark center.

Mary Gray. Reddish purple, narrow white lacing.

Souv. de Sale. Soft rosy pink, very double.

White Reserve. Pure white, fringed.

Field grown plants 15c each, $\$ 1.50$ per dozen; by express, 10c each; $\$ 1.00$ per dozen.

\section{IRIS GERMANICA (German Iris)}

The true "Fleur-de-Lis," the national flower of France. They are perfectly hardy, thrive anywhere, grow and bloom luxuriantly, particularly if plentifully supplied with water or if planted in moist situations, as on banks of ponds, etc. Plants well established produce from 50 to 100 spikes of bloom, deliciously fragrant and fine for cutting. Colors range through richest yellows, intense purples, delicate blues, soft mauves, beautiful claret reds, white, primrose and bronzes of every imaginable shade.

Canary Bird. Falls creamy white, uppers light canary yellow; medium sized flower.

Celeste. Falls bright blue, uppers delicate grayish blue; all having a lavender effect. $15 \mathrm{c} ; \$ 1.50$ per dozen.

Conspicua. Falls deep maroon, uppers buff and yellow; large flowered.

Cubero. Rich orange yellow, lower petals streaked maroon.

Florentina Alba. Sweet scented, free flowering white.

Fulda. Satiny white; lower petals lilac, feathered yellow.

Her Majesty. Falls crimson over white, giving flower a slightly striped effect; uppers bright lavender rose. A fine large flower. 
Honorabilis. Fine yellow uppers, with lower petals of maroon.

Mad. Chereau. Very delicate and distinct; white, edged blue. 15c; $\$ 1.50$ per doz.

Mrs. H. Darwin. Falls satiny white, veined crimson; uppers white with slight crimson penciling at base. 15c; $\$ 1.50$ per dozen.

Parisensis. Large, showy, deep purple, delicately penciled white.

Unless noted, 10c each; \$1.00 per dozen; \$6.50 per 100.

\section{IRIS KAEMPFERI (Japan Iris)}

Finest of all the Iris family. The flowers are of immense size, from six to eight inches in diameter, and of the most beautiful and delicate shades.

Mixed Varieties. 15 ceach; \$1.50 per dozen; \$10.00 per 100.

Aquilegia (Columbine). The distinct, clear-cut foliage and delicate arrangement of colors in the flowers of Columbine make it one of the showiest and most desirable of the hardy garden plants; especially suitable for rockwork, at the base of foundation walls and under trees.

-Canadensis. The native Columbine, with bright red and yellow flowers.

-Chrysantha. The "Golden Spur" Columbine.

-Caerulea. The .dainty "Rocky Mountain Columbine," blue and white.

Campanula Carpatica (Carpathian Hare-Bell). A pretty compact species, not exceeding eight inches high, flowers clear blue, one inch in diameter.

-Carpatica Alba. White flowering.

Campanula Media (Canterbury Bells). The well known "Canterbury Bells." Blooms in July, height 2 to 3 feet. Blue, rose or white.

-Persicifolia (Peach Bells). $1 \frac{1 / 2}{2}$ to 2 feet high, blue, salver-shaped flowers.

-Alba. White flowered.

-Pyramidalis (Chimney Bell-flower). Very conspicuous; 4 to 5 feet high. Salver-shaped blue flowers borne profusely in September.

-Alba. Corresponding white flower.

Coreopsis Lanceolata Grandiflora. The perfected strain of a long popular hardy plant. Flowers are rich golden yellow, borne in great profusion nearly the entire summer. $10 c ; \$ 1.00$ per dozen. 
Delphinium (Perennial Larkspur). Indispensable to the herbaceous garden. Their long, showy spikes of flowers persist from June till frost and furnish the most satisfactory blues to any color scheme.

-Chinensis. Fine stems and deeply cleft foliage; flowers showing all lighter shades of blue. 18in. 10c; $\$ 1.00$ per dozen.

-Alba. Pure white flowers. 10c; $\$ 1.00$ per dozen.

-Formosum. The old fashioned very dark blue variety. Three to four feet. 10c; $\$ 1.00$ per dozen.

-Coelestinum. A charming delicate blue. 10c; \$1.00 per dozen.

- Hybridum. A choice strain of Hybrids embracing all shades of blue and purple. 10c; $\$ 1.00$ per dozen.

Dictamnus Rubra (Gas Plant). Fragrant foliage, spikes of curious red flowers. $10 \mathrm{c} ; 12$ for $\$ 1.00$.

Digitalis (Foxglove). Old fashioned plants which furnish a grand display of flowers in immense spikes in July and August.

-Alba. White.

-Rosea. Rose. 10c; $\$ 1.00$ per dozen.

Helianthus (Sunflowers). Very profitable for summer cutting and massy display.

-Maximilliana. Immense single flowers, rich golden yellow, center reddish brown. 5 to 7 feet.

-Mollis Grandiflorus. Light lemon yellow, large single. Foliage quite hairy. 4 feet.

-Multiflorus Plenus. Large double yellow. 4 feet.

-Orgyalis. 6 to 8 feet tall, branched near summit; foliage dense and gracefully drooping. Single, lemon yellow flowers in abundance. 20c; \$2.00 per dozen.

-Rigidus. Of fine upright habit of growth. Flowers light yellow with maroon center. 3 feet. 10c; $\$ 1.00$ per dozen.

Soliel d'Or. Clear yellow; closely resembling a Cactus Dahlia in shape and finish. 4 feet.

-Heliopsis Pitcheriana (Orange Sunflower). Pretty Daisylike flowers, orange yellow, with a pyramidal center of darker shade.

Hemerocallis (Day Lilies). Very effective in clumps and masses, numerous panicles of orange and yellow Lilylike flowers protruding high above the grass-like foliage.

-Dumortieri. Dwarf and compact; 2 feet; flowers orange. 10 ; 12 for $\$ 1.00$. 
-Flava (Lemon Lily). Crowned by beautiful lemon-colored flowers 3 to 4 inches in diameter, and delightfully fragrant. 3 feet. 20c; 12 for $\$ 1.50$.

- Kwanso fl. pl. (Double Orange Lily). Large, double, copper colored flowers. $15 \mathrm{c} ; 12$ for $\$ 1.50$.

Funkia-Cordata (Day Lily). Wide circles of broad leaves. Flowers large, waxy white, borne in large trusses. Very fragrant.

Gaillardia Grandiflora (Blanket Flower). Makes one of the most gorgeous and prodigal displays of all perennials. Flowers often measure 3 inches in diameter, on clean 2 feet stems. A hard center of deep maroon is thickly bordered by petals of orange and yellow, strikingly ringed by circles of crimson, red and maroon. Poor soil will do, and a constant show is assured from June till frost. 10c; $\$ 1.00$ per dozen.

Hibiscus Moscheutos. The fine old Swamp Rose Mallow. Large purplish pink flower with large dark eye. Four to five feet. 10c; $\$ 1.00$ per dozen.

Hibiscus Crimson Eye. Immense flowers of purest white, with large centers of velvety crimson. 10c; $\$ 1.00$ per dozen.

Hollyhocks. Crimson, yellow, white, pink. 10c; \$1.00 per dozen.

-Mammoth Fringed. Extra large flowers, in mixed colors. Finely curled and fringed. 15 ; 8 for $\$ 1.00$.

Papaver Nudicaule (Iceland Poppy). Cup shaped, white, yellow and orange.

-Orientale. The brilliant "Oriental Poppy," with large and flaming flowers of orange-scarlet.

-Bracteatum. A charming species, with immense deep blood-crimson flowers, having a black blotch at the base of each petal.

Platycodon Grandiflorum (Balloon Flower). Blooms constantly from July until late in September; flowers large bell-shaped, of a deep shade of blue. An extremely rapid grower, doing well in any ordinary soil. Perfectly hardy, making a dense branching bush 2 to 3 feet high. 10c; \$1.00 per dozen.

-Album. Pure white flowers. 10c; \$1.00 per dozen.

Pyrethrum Roseum. Foliage fine-cut and attractive; flowers borne profusely on long straight stems, colored in all shades of rose. A splendid cut flower and conspicuous in the garden. 
Rudbeckia (Golden Glow). The most prolific and satisfactory hardy perennial of all yellow flowering sorts. Grows 5 to 7 feet and blooms from early summer until frost. Flowers are produced on long stems in enormous quantities, and resemble golden-yellow Cactus Dahlia.

. 10c; 75c per dozen.

Rudbeckia Purpurea (Purple Coneflower). Large drooping petals colored reddish-purple, with a remarkably large cone-shaped center of brown, thickly set with golden tips in spiral lines. 2 to 3 feet.

-Newmani. Grows $1 \frac{1}{2}$ to 2 feet; plentifully supplied with broad single flowers of orange-yellow, with a prominent brown cone.

Shasta Daisy. Large snowy-white flowers, in bloom continuously throughout the summer and fall. Splendid cutters.

Stokesia Cyanea (Stoke's Aster). One of the most charming hardy plants, freely blooming from July to October. Flowers of Centaurea shape, often measure 4 to 5 in. across, making a rich show of lavender-blue. $1 \frac{1}{2}$ to 2 feet. 10c; \$1.00 per dozen.

Yucca Filamentosa (Adam's Needle or Spanish Bayonet). A stately foliage and flowering plant equally imposing in solitary or group plantings, always conspicuous. The broad sword-like foliage is evergreen; while midsummer shows great erect branching stems bearing a showy display of pendant, creamy-white bells. 10c; $\$ 1.00$ per dozen. Strong 3 -year, by express, 25c; $\$ \mathbf{\$ 2 . 5 0}$ per dozen.

Tritoma (Red Hot Poker).

Pfitzeri. An improved type of more perfect form, and showing a marked predominance of scarlet-the opened lower petals, merely, being rimmed with orange.

Prices unless noted on any of the foregoing, 15c; \$1.25 doz.

\section{HARDY POMPON CHRYSANTHEMUMS.}

These small flowered 'Mums are becoming very popular again, as they are the only perfectly hardy ones we have, and give showers of bloom long after frost in the fall, after most other flowers are gone.

The Baby 'Mum. Smallest and prettiest of the Pompons; bright, golden yellow, the individual flower being onehalf to five-eighths of an inch in diameter, quilled. A perfect pot plant, also valuable for cut sprays. 15c; 2 for $25 c$; 1 dozen $\$ 1.25$. 
Alena-Good sized, beautiful daybreak pink.

Attila-Light apricot, tinted rose.

Delicatissima-Lower petals pale pink, center deep wine.

Gallia-Light rosy pink.

Little Bob-Small red flowers; very free.

Livan-White, edged pink.

Mary Williamson-White, changing to pink.

Nita-Large flowered, rosy pink.

Oneita-Large well formed flowers, clear yellow.

Oriole-Yellow, marked with crimson.

Princess Louise-Fine deep pink, large.

Snowdrops-Pure white.

Utan-Light magenta, edged and tipped white.

Viola-Deep violet, very showy and distinct.

White Flora-Pure white, large flowered.

Zenobia-Bright pure yellow.

Zorla-Bright magenta-pink; very dwarf and free flowering. 15c.

Unless noted, 10c each; 20, our choice, \$1.00.

\section{HARDY CLIMBING VINES.}

Ampelopsis Veitchii (Boston Ivy). One of the finest climbers for covering walls. Will cling to the smoothest surface. $15 \mathrm{c}$ each; $\$ 1.50$ per dozen.

Quinquefolia. Virginia Creeper. 15c; $\$ 1.50$ per dozen. Bignonia Radicans (Trumpet Flower). A robust, woody vine, splendid for covering posts, stumps, etc. 20c.

Clematis Henryi. Large creamy white flowers. 50c.

- Jackmanii. Velvety violet purple flowers. 50c.

-Mad. Ed. Andre. Crimson red flowers. 50c.

-Ramona. Large, deep sky-blue flowers. 50c.

- Paniculata (Sweet Scented Japan). Very rapid growth, medium sized pure white flowers, completely covering the vine in September. 15c; 2 yr. 25c; $\$ 2.50$ per doz.

Lonicera Aurea Reticulata (Golden Leaved Honeysuckle). Flowers yellow and fragrant. 10c; $\$ 1.00$ per dozen.

-Belgica (Monthly Fragrant). Flowers large and very fragrant, color red and yellow. 20c; $\$ 2.00$ per doz.

Sempervirens (Scarlet Trumpet Honeysuckle). Trumpet shaped flowers of bright scarlet. 20c; $\$ 2.00$ per doz.

Wistaria Magnifica. Flowers in dense droopiny racemes, pale lavender color. 25c. 


\section{AS TO SHIPPING CHARGES.}

All prices quoted in this list are by mail, postpaid. Large plants, large lots, such as gladioli and dahlias in 100 lots are by express or freight, carriage collect. Express rate on plants and bulbs is about 20 per cent less than merchandise rates. I advise ordering this way where distance is not too great as I can furnish much larger and stronger stock.

I make no prices on sets of plants or seeds. Should a set be wanted please allow me to quote prices. They will often be lower than would be quoted in the list as many times we are overstocked on varieties of real merit that for some reason will move slowly.

On all orders too large to be sent by mail price will be made so that express rate will be balanced.

On account of the cost of packing, which on small orders often amounts to more than the sum received, please see that plant orders amount to $\$ 1.00$ or more.

I GUARANTEE to replace stock that proves unsatisfactory from any cause, and to see that you are successful with any stock bought from me provided my advice is taken with regard to rarieties and handling in your location.

I would be pleased to act as your agent for specimen ornamental trees, shrubs, fruit trees, small fruits or anything in the nursery line. I am located in the largest nursery center in the world and can suit you both in quality and price. 



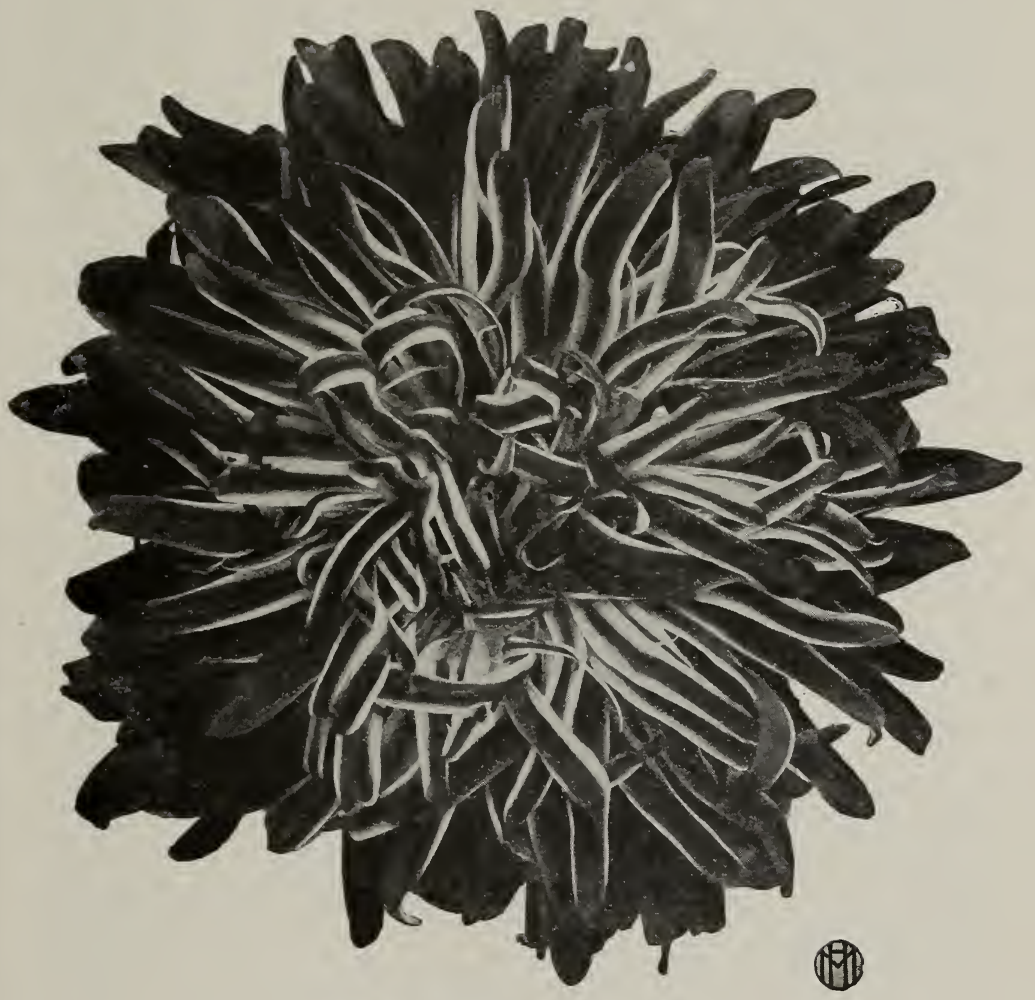

Ruby and White Comet Aster.

Mette. 



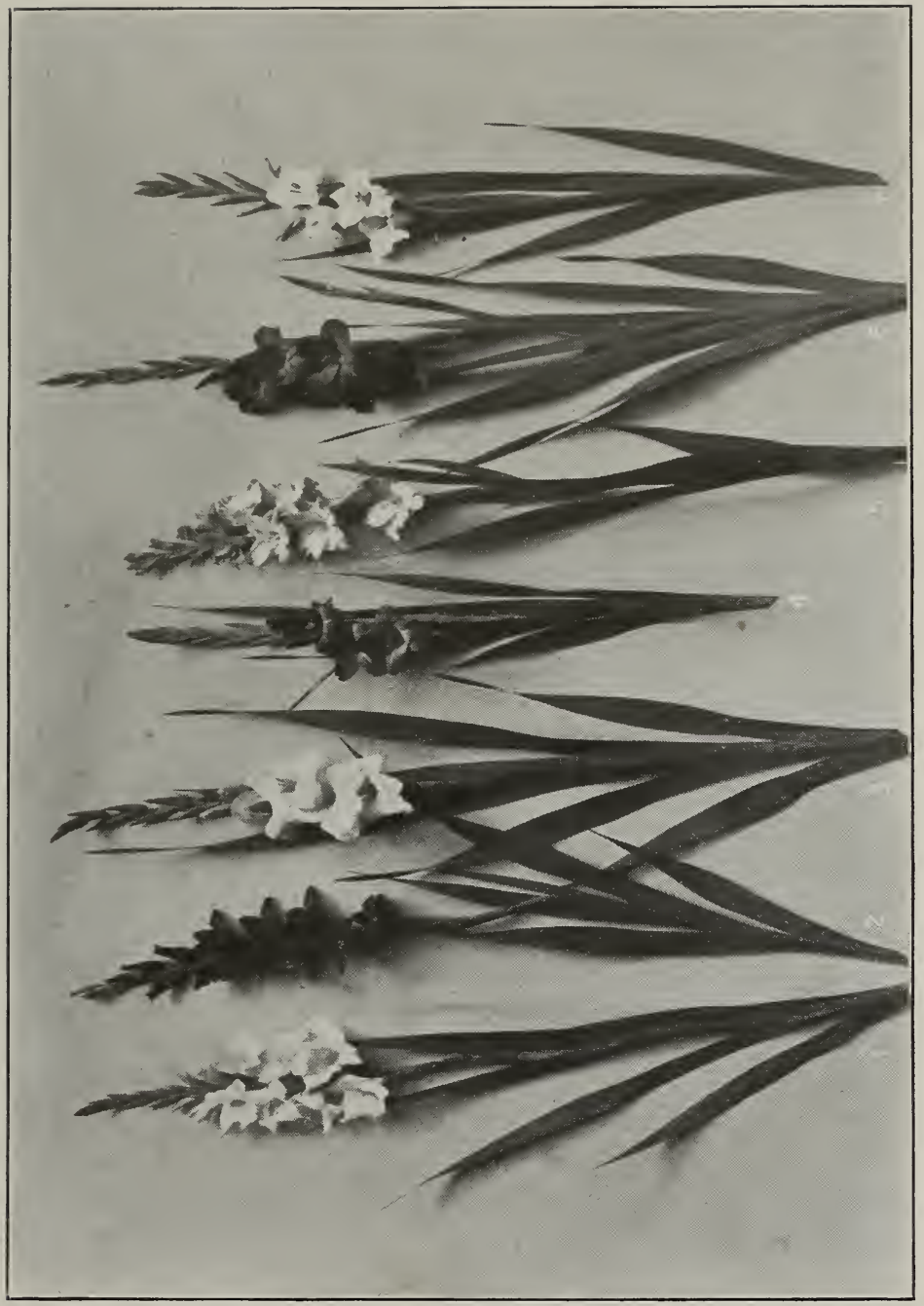





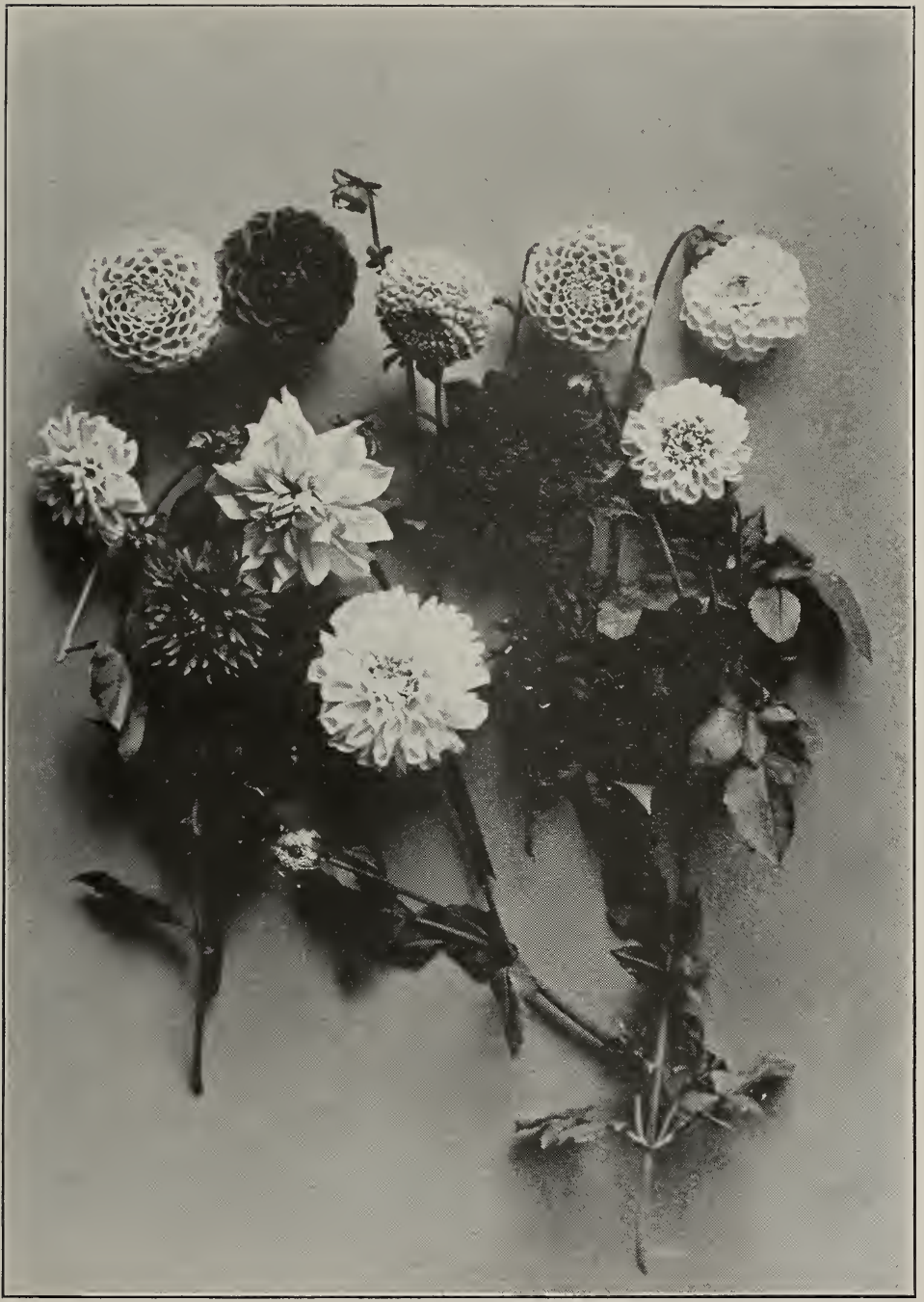





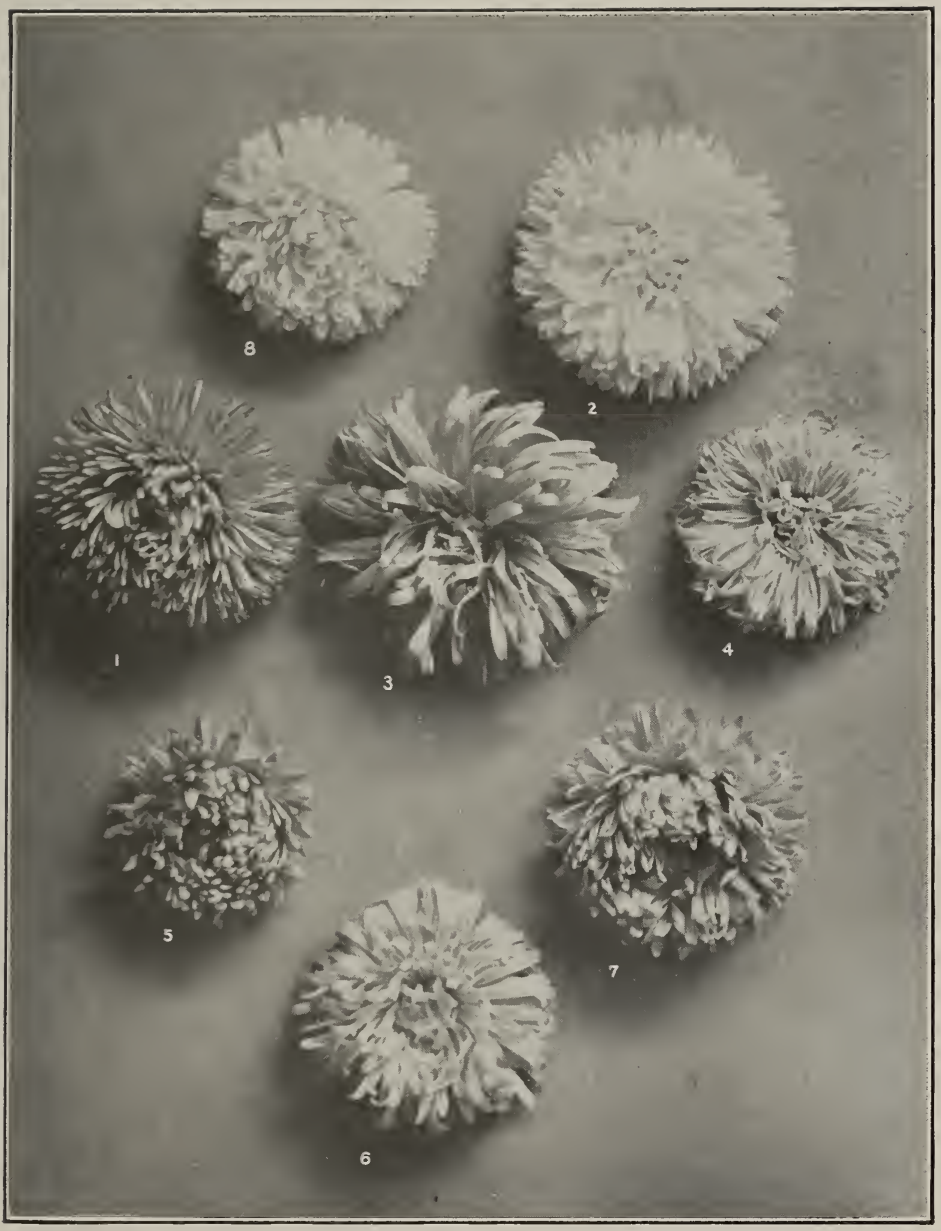




